\title{
ADSORPTION OF AFLATOXIN B1 IN CORN ON NATURAL ZEOLITE AND BENTONITE
}

\author{
Nuryono $^{1, *}$, Ali Agus $^{2}$, Sri Wedhastri ${ }^{3}$, Y.M.S. Maryudhani ${ }^{3}$, \\ Deni Pranowo ${ }^{1}$, Yunianto ${ }^{4}$, and Ebrahim Razzazi-Fazeli ${ }^{5}$ \\ ${ }^{1}$ Department of Chemistry, Faculty of Mathematics and Natural Sciences, Universitas Gadjah Mada, \\ Jl. Sekip Utara, Yogyakarta 55281 \\ ${ }^{2}$ Faculty of Animal Science, Universitas Gadjah Mada, Yogyakarta, Indonesia \\ ${ }^{3}$ Faculty of Agriculture, Universitas Gadjah Mada, Yogyakarta, Indonesia \\ ${ }^{4}$ Animal Husbandry Academy Brahma Putra, Yogyakarta, Indonesia \\ ${ }^{5}$ Proteomic Unit, VetCore Facility for Research, University of Veterinary Medicine, Vienna, Austria
}

Received June 19, 2012; Accepted October 27, 2012

\begin{abstract}
A study on adsorption of AFB1 in corn (kernel and grained) on natural zeolite and bentonite has been investigated. The first work was adsorption in a batch system of standard AFB1 solution on adsorbents. Some factors such as contact time, concentration of AFB1 and particle size of adsorbent were evaluated. The amount of AFB1 adsorbed was calculated based on the difference of AFB1 concentration before and after adsorption determined by high performance liquid chromatography (HPLC) method. Adsorption of AFB1 in corn sample was emphasized by mixing aqueous suspension of sample with adsorbent. Concentration of AFB1 in suspension was analyzed by enzyme-linked immuno-sorbent assay (ELISA) method. Result shows that adsorption of AFB1 on adsorbents of natural zeolite and bentonite is very fast. Within $15 \mathrm{~min} 99 \%$ of AFB1 (200 $\mathrm{ng} / \mathrm{mL})$ has been adsorbed by $25 \mathrm{mg}$ of bentonite and $96 \%$ by zeolite. The particle size higher than 200 mesh did not give significant effect on the AFB1 adsorption capability. Effectiveness of zeolite in adsorbing AFB1 is lower than that of bentonite. Capability in reducing AFB1 contamination in corn samples (kernel and meal) for both adsorbents is lower than that in standard solution.
\end{abstract}

Keywords: aflatoxin; corn; adsorption; bentonite; zeolite

\begin{abstract}
ABSTRAK
Kajian penurunan kadar aflatoksin B1 (AFB1) dalam jagung (kernel dan butiran) melalui teknik adsorpsi dengan zeolit dan bentonit alam sebagai adsorben telah dilakukan. Langkah pertama adalah adsorpsi AFB1 standar pada adsorben dalam sistem batch. Beberapa faktor, yaitu waktu kontak, konsentrasi AFB1 dan ukuran partikel adsorben telah dievaluasi. Jumlah AFB1 yang teradsorpsi dihitung berdasarkan selisih konsentrasi AFB1 sebelum dan sesudah adsorpsi dan ditentukan dengan kromatografi cair kinerja tinggi (KCKT). Adsorpsi AFB1 dalam sampel jagung dikerjakan dengan mencampur suspense sampel jagung dalam air dan adsorben. Konsentrasi AFB1 dalam suspensi dianalisis dengan metode enzyme-linked immuno sorbent assay-(ELISA). Hasil menunjukkan bahwa adsorpsi AFB1 pada adsorben zeolit dan bentonit alam sangat cepat. Dalam waktu 15 menit 99\% dari AFB1 (200 ng/mL) telah terserap oleh $25 \mathrm{mg}$ bentonit dan 96\% oleh zeolit. Ukuran partikel lebih tinggi dari 200 mesh tidak memberikan dampak signifikan terhadap kemampuan adsorpsi AFB1. Efektivitas adsorpsi zeolit terhadap AFB1 lebih rendah daripada bentonit. Kedua adsorben memiliki kemampuan mengadsorpsi AFB1 dalam sampel jagung (kernel dan butiran) lebih rendah dibandingkan dalam larutan standar.
\end{abstract}

Kata Kunci: aflatoksin; jagung; adsorpsi; bentonit; zeolit

\section{INTRODUCTION}

Aflatoxins are a mycotoxin group possessing highly carcinogenic, mutagenic, and teratogenic properties [12]. There are seventeen aflatoxins that have been isolated, however, only four, so called B1, B2, G1 and

* Corresponding author.

Email address : nuryono_mipa@ugm.ac.id
G2, are significant contaminants of foods and feeds, and aflatoxin B1 is the most acutely toxic of the aflatoxins [3].

In Indonesia, aflatoxins are frequently found in agriculture commodities and their derivatives [4-5]. In addition, residue and its metabolites are also obtained

Nuryono et al. 
in husbandry products such as milk [6-7], eggs [8], and chicken meat [9]. Contamination of maize and other food commodities with aflatoxins is a public health concern because of the ability of aflatoxins to cause human and animal diseases. Aflatoxins have been implicated with acute and chronic aflatoxicosis, genotoxicity, hepatocellular carcinoma, suppression of the immune system, aggravation of kwashiorkor and impaired childhood growth [10]. Outbreaks of acute human aflatoxicosis occur frequently especially with respect to maize, the dietary. Sudjadi [11] reported that 80 among 81 patients (66 males and 15 females) experience lever cancer and it was suspected because they consumed soya fermented, fried peanut, peanut spices and soya sauce. Mycotoxins of $\mathrm{AFB}_{1}, \mathrm{AFG}_{1}$, and $\mathrm{AFM}_{1}$ were detected in the samples of lever collected from $58 \%$ of patients with the concentration more than $400 \mu \mathrm{g} / \mathrm{kg}$.

Numerous strategies, such as physical separation, thermal inactivation, irradiation, microbial degradation and treatment with a variety of chemicals have been used for the detoxification or inactivation of mycotoxincontaminated feedstuff [12]. One strategy is to bind the aflatoxin molecule to a compound that cannot be absorbed from the animal's digestive tract. The bound aflatoxins are then excreted in the faeces [13].

It was also reported that phyllosilicates clay has the ability to chemisorb aflatoxin from aqueous solutions [14]. Some aluminosilicates bind AFB1 in vitro to varying degrees and form complexes of varying strength with AFB1. The hydrated sodium calcium aluminosilicate (HSCAS) formed a more stable complex with AFB1 than many of the other compounds tested in vitro. The HSCAS, bentonite and montmorillonite were found to protect the laboratory animals from the toxic and teratogenic effects of aflatoxins [15].

Aly et al. [16] reported result of study on adsorption of AFB1 and FB1 onto a commercially hydrated sodium calcium aluminosilicate (HSCAS) and Egyptian montmorillonite (EM) in an aqueous solution at different tested levels. The adsorption ratio of HSCAS ranged from 95.3 to $99.1 \%$ and 84.7 to $92.4 \%$ of the available AFB1 and FB1 respectively. EM showed an adsorption ratio ranged from 95.4 to $99.2 \%$ and 78.2 to $92.2 \%$ for AFB1 and FB1 respectively. Both adsorbents were effective at $0.5 \%$ level. Results of the ability of these adsorbents at level of $0.5 \%(\mathrm{w} / \mathrm{v})$ to adsorb AFB1 and FB1 in malt extract spiked with 50, 100 and 200 ppb indicated that the capability of adsorbing of HSCAS ranged from 98.5 to $98.9 \%$ and 88.2 to $91.9 \%$ for AFB1 and FB1 respectively. Whereas, the capability of adsorbing of EM ranged from 98.1 to $98.7 \%$ and 88.2 to $92.5 \%$ for AFB1 and FB1, respectively.

The isothermal adsorption and the adsorptive mechanism of aflatoxin B1 (AFB1) on calcium montmorillonite (Mont) were studied in vitro trials [17].
The maximum amounts of AFB1 on Mont in aqueous solution at 2 and $\mathrm{pH} 8$ were 613.5 and $628.9 \mu \mathrm{g}$ of AFB1/g of Mont, respectively. The Mont, when added to the diet of broiler chicken at $0.5 \%$, significantly diminished the adverse effects of feeding $200 \mu \mathrm{g}$ of AFB $1 / \mathrm{kg}$ of feed. And the concentrations of $\mathrm{Ca}, \mathrm{P}, \mathrm{Cu}$, $\mathrm{Fe}, \mathrm{Zn}$ in the broiler bones were not affected by AFB1 and Mont, but the concentrations of $\mathrm{Mn}, \mathrm{Pb}$, and $\mathrm{F}$ were decreased by Mont.

Thieu and Pettersson [18] reported results of an in vitro study using single concentration and isotherm adsorption to evaluate the capacity of Vietnamese produced zeolite and bentonite to adsorb aflatoxin $B_{1}$ $\left(\mathrm{AFB}_{1}\right.$ ) in simulated gastrointestinal fluids (SGFs), and a commercial sorbent hydrated sodium calcium aluminosilicate (HSCAS) was used as reference. Adsorption of $\mathrm{AFB}_{1}$ onto zeolite and bentonite varied according to the $\mathrm{pH}$ of SGFs and was lower than HSCAS. Linearity between the increased amount of $\mathrm{AFB}_{1}$ adsorbed on sorbents and the decrease of sorbent concentration was observed for bentonite and HSCAS, except for zeolite in SGFs at pH 7. The observed maximum amounts of $\mathrm{AFB}_{1}$ adsorbed on bentonite and HSCAS were 1.54 and $1.56 \mathrm{mg} / \mathrm{g}$, respectively. The adsorption capacities of bentonite and HSCAS for $\mathrm{AFB}_{1}$ were 12.7 and $13.1 \mathrm{mg} / \mathrm{g}$, respectively, from fitting the data to the Freundlich isotherm equation.

Eight potential aflatoxin-sequestering agents (SAs) were tested for their ability to adsorb aflatoxin B1 (AfB1) and aflatoxin $\mathrm{G} 1$ (AfG1) in vitro. They belong to main SA classes: silicate minerals (calcium, magnesium and sodium bentonites, kaolinite, zeolite and clinoptinolite), activated carbon and yeast cell wallderived [19]. The $\mathrm{Ca}$ bentonite and clinoptinolite were able to bind available AfB1 in MM and RM methods, while they appeared inefficient (available AfB1 sequestered less than $80 \%$ ) when $\mathrm{W}$ was used. The adsorption ability of zeolite was confirmed only with the W method. Ineffective or limited sequestering activity was obtained with kaolinite and yeast cell wall-derived products with each method. The AFB1 and AFG1 sequestering efficiencies observed in the present work resulted very similar showing strong and positive correlation $(P<0.001)$ within methods $(r=0.79, r=0.96$ and $r=0.99$, respectively for $\mathrm{W}, \mathrm{MM}$ and $\mathrm{RM}$ methods). The two simulated gastrointestinal methods (MM and RM, respectively) gave similar results and could be considered useful for in vitro pre-screening of potential sequestering agents.

The present paper reports a research studying capability of Indonesian natural bentonite and zeolite to adsorb aflatoxin B1 in aqueous solution, and the application of this technique for the reduction of FB1 
from aqueous solution during the extraction of kernel and grain corn samples.

\section{EXPERIMENTAL SECTION}

\section{Materials}

Standard solution of AFB1 in toluene : acetonitrile (9:1) $25.92 \mathrm{ng} / \mathrm{mL}$ was prepared by dissolving powder of AFB1 standard purchased from Sigma Chemical Co., St. Louis, MO. Working standard solutions used for HPLC analysis were $25,50,100$ and $200 \mathrm{ng} / \mathrm{mL}$. HPLC eluent consisted of double distillated water, methanol (JT Baker, USA) and acetonitrile (Fisher Scientific, USA) in HPLC grade used without pre-treatment. ELISA kit of AFB1 (Ridascreen ${ }^{\circledR}$ ) was used for analysis of AFB1 in corn suspension.

Kernel Corn sample ( $P 21$ hybrid) $5 \mathrm{~kg}$ was collected from Klaten district (Central Java) with water content of $15-18 \%$. Apart of the sample was grounded in order to get the particle size similar to that for cattle ransom. To prepare AFB1 contaminated corn, the sample was grown up with fungi producing aflatoxin (Aspergillus Flavus) for two weeks.

Bentonite sample was collected from a source location in Pacitan district (East Java) and zeolite was sampled from Wonosari district, Yogyakarta. The samples were dried in an oven at $110{ }^{\circ} \mathrm{C}$ for $2 \mathrm{~h}$ and grounded in order to give various particle sizes $(80,100$, 200 and 400 mesh).

\section{Instrumentation}

A shaking (GFL 3015) and centrifuge (Eppendorf, 5810R) apparatus were used for adsorption and separation, respectively. For analysis of AFB1 was used a set of HPLC system consisting of a delivery pump (LDC Analytical, constametricR 4110, USA), an autosampler (Hitachi, AS 2000, Japan), a fluorescence detector (Shimadzu RF 535, Japan) and a HPLC column $(25 \times 4.6 \mathrm{~mm}$, Keystone Scientific, INC). Analysis of AFB1 in corn sample was carried out by using ELISA (Enzyme-linked immunosorbent assay) method using and a Micro-plate Reader Type 550122 (Bio-Rad Laboratories, Richmond, CA, USA).

Characterization of zeolite and bentonite was carried out with infrared spectrophotometer and x-ray diffraction method for identifying functional groups and crystalline level of adsorbent, respectively.

\section{Procedure}

\section{Adsorption of standard AFB1 on adsorbents}

Adsorption was emphasized in a batch system. Adsorbent $25 \mathrm{mg}$ was mixed with $5.0 \mathrm{~mL}$ of AFB1 aqueous solution in plastic container. The mixture was shaked mechanically and centrifuged. Concentration of AFB1 in supernatant was determined using HPLC method with mobile phase of water : methanol : acetonitrile 62:32:16 (\% v/v) at a flow rate of $1.0 \mathrm{~mL} / \mathrm{min}$. The amount of AFB1 adsorbed $(\mathrm{ng} / \mathrm{mg})$ was calculated with the following equation:

$\mathrm{m}=\frac{\left(\mathrm{C}_{\mathrm{o}}-\mathrm{C}\right) \mathrm{V}}{\mathrm{M}}$

where $C_{0}$ and $C$ are initial and final concentration, respectively, $(\mathrm{ng} / \mathrm{mL})$ of AFB1. $V$ is volume of solution $(\mathrm{mL})$ and $M$ is adsorbent weight $(\mathrm{g})$. The above work was done for both adsorbents (zeolite and bentonite). Three variables including contact time, initial concentration of AFB1 and particle size of adsorbents were investigated. The variable of contact time was varied from 15 to $180 \mathrm{~min}$, the initial concentration was from 200 to $2000 \mathrm{ng} / \mathrm{mL}$ and four different particle sizes $(80,100,200$ and 400 mesh) were examined.

\section{Reduction of AFB1 in corn suspension}

Reduction was carried out similar to the adsorption of AFB1 in standard solution. Corn samples (kernel and grounded form) $5 \mathrm{~g}$ and adsorbent were suspended with $15 \mathrm{~mL}$ and shaked mechanically for $2 \mathrm{~h}$. The weight of adsorbent was varied from 25 to $1000 \mathrm{mg}$. The suspension was filtered and AFB1 in the filtrate was analyzed with ELISA method at $450 \mathrm{~nm}$. The amount of AFB1 adsorbed was calculated by subtracting initial concentration of AFB1 in filtrate (without addition of adsorbent) with concentration of filtrate after adsorption.

\section{RESULT AND DISCUSSION}

\section{Adsorbent Characters}

Characterization of adsorbents was carried out by two techniques, namely $x$-ray diffraction and infrared spectroscopic methods for identification of crystalline level and functional groups, respectively. Infrared spectra were expressed in Fig. 1.

Absorbance pattern in infrared spectra of bentonite (Fig. 1(a)) may be interpreted as follows: absorbance band at $3448.5 \mathrm{~cm}^{-1}$ indicates vibration of hydroxyl groups from silanol ( $\mathrm{Si}-\mathrm{OH})$ or/and aluminol (Al-OH). Strong and sharp absorbance at $1049.3 \mathrm{~cm}^{-1}$ is asymmetric stretching vibration from $\mathrm{T}-\mathrm{O}$ groups $(\mathrm{T}=\mathrm{Si} / \mathrm{Al})$ in silica $(\mathrm{Si}-\mathrm{O}-\mathrm{Si}$ ) and/or alumina (Al-O-Al). Band at $956.6 \mathrm{~cm}^{-1}$ is predicted as stretching vibration from $\mathrm{Si}-\mathrm{O}$ in $\mathrm{Si}-\mathrm{OH}$ or $\mathrm{Al}-\mathrm{O}$ in $\mathrm{Al}-\mathrm{OH}$. Stretching vibration of $\mathrm{Si}-\mathrm{O}-\mathrm{Si}$ is showed at $794.5 \mathrm{~cm}^{-1}$ and bending vibration from $\mathrm{Si}-\mathrm{O}-\mathrm{Si}$ or $\mathrm{Al}-\mathrm{O}-\mathrm{Al}$ gives absorbance at $474.5 \mathrm{~cm}^{-1}$. The band at $1635.5 \mathrm{~cm}^{-1}$ is resulted from bending vibration of $-\mathrm{OH}$ groups from 


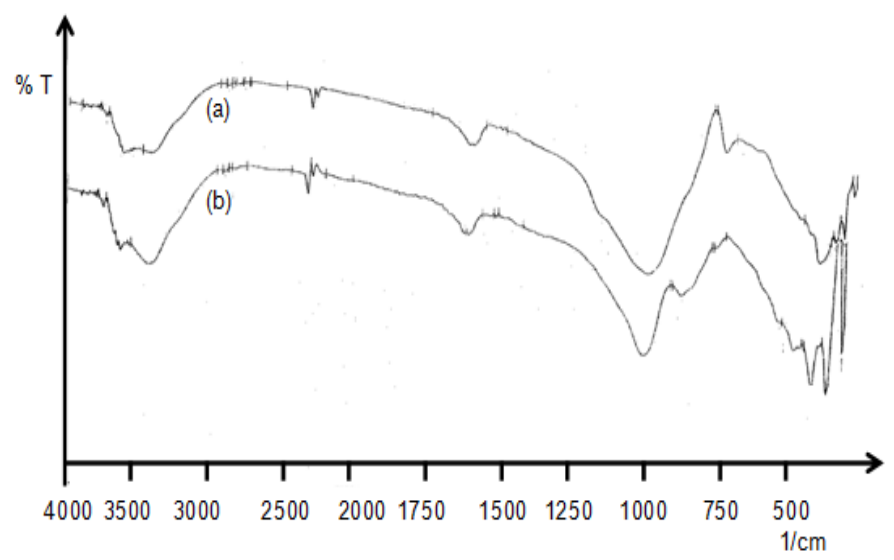

Fig 1. Infrared spectra of bentonite (a) and zeolite (b)

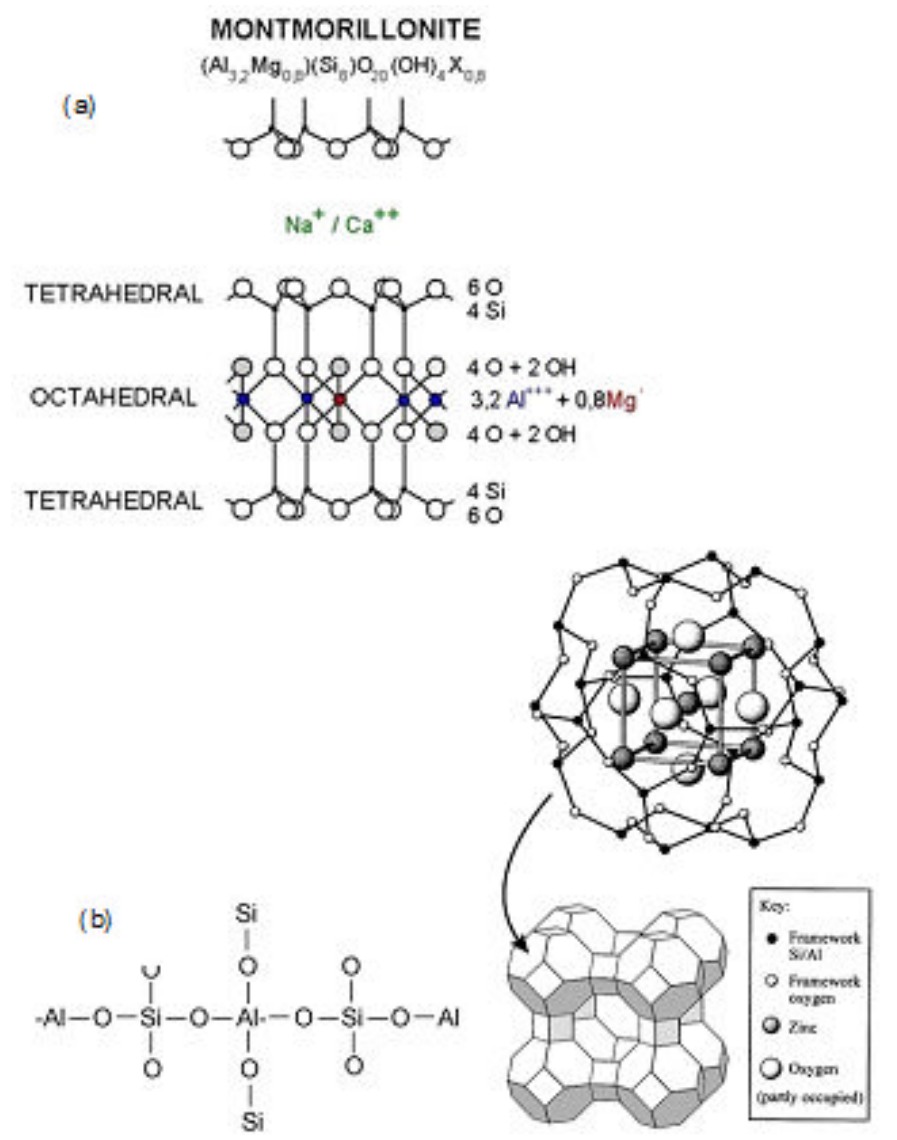

Fig 2. Structure Model of bentonite (a) and zeolite (b)

$\mathrm{T}-\mathrm{OH}$. In general, absorbance band in infrared spectra of bentonite informs that functional groups present are silanol/aluminol (T-OH) and T-O-T groups. It is observed that infrared spectra of zeolite (Fig. 1(b)) give similar spectra of bentonite indicating similarity of the presence of functional groups. The difference lies on the absorbance intensity.

Although the functional group in bentonite and zeolite are similar, the structure of both materials is
Table 1. XRD patent of adsorbents

\begin{tabular}{lccl}
\hline Adsorbent & $2 \theta\left({ }^{\circ}\right)$ & $\mathrm{d}\left({ }^{\circ} \mathrm{A}\right)$ & \multicolumn{1}{c}{ Minerals } \\
\hline Bentonite & 22.45 & 3.957 & Montmorillonite \\
& 27.91 & 3.194 & \\
& 25.88 & 3.440 & \\
\hline Zeolite & 27.95 & 3.190 & modernite, \\
& 5.82 & 15.170 & levynite and \\
& 5.54 & 15.939 & analsime \\
\hline
\end{tabular}

Table 2. Freundlich parameters for adsorption of AFB1 on adsorbents

\begin{tabular}{lccc}
\hline Adsorbent & $K_{f}$ & $n$ & $R^{2}$ \\
\hline Zeolite & 1.39 & 0.63 & 0.9713 \\
Bentonite & 5.33 & 0.68 & 0.9939 \\
\hline
\end{tabular}

different. From Table 1 can be seen that XRD data gives three big peaks at $2 \theta 22.45,27.91$ and 25.88 with d $3.957,3.194$ and $3.440{ }^{\circ} \mathrm{A}$. Those indicate characteristic values for the structure of montmorillonite and as the main component of the bentonite. The structure model of montmorillonite is expressed in Fig. 2(a). From data of XRD for zeolite summarized in Table 2 can be stated that the main components of zeolite are modernite, levynite and analsime.

\section{Adsorption of Standard AFB1 in Aqueous Solution}

Analysis of AFB1 used for the adsorption process was HPLC and by using optimum condition, it was found that AFB1 gave chromatographic peak at retention time of $19.15 \mathrm{~min}$ (Fig. 3). Evaluation of standard working solution expressed with standard curve shows higher linearity with coefficient correlation $\left(R^{2}\right)$ of 0.9998 .

\section{Effect of Contact Time and Adsorbent Particle Size}

Experiment to examine the effect of contact time on the adsorption of standard AFB1 was emphasized by varying contact time from 15 to $180 \mathrm{~min}$ at concentration of AFB1, adsorbent weight and particle size constant, namely $2 \mu \mathrm{g} / \mathrm{mL}, 25 \mathrm{mg}$ and 200 mesh, respectively. The analogue step was done for other variables. Result is expressed in Fig. 4 for the effect of contact time and Fig. 5 for particle size effect. From Fig. 4 can be seen that adsorption of AFB1 on both zeolite and bentonite is very fast. Within $15 \mathrm{~min}$, the process reaches equilibrium. Due to the technical reason, process less than $15 \mathrm{~min}$ is not possible to be carried out; hence adsorption kinetics could not be quantitatively evaluated.

Fig. 5 shows that adsorption capability increases with smaller particle size. For four different particle sizes may be classified into two groups' namely big size 


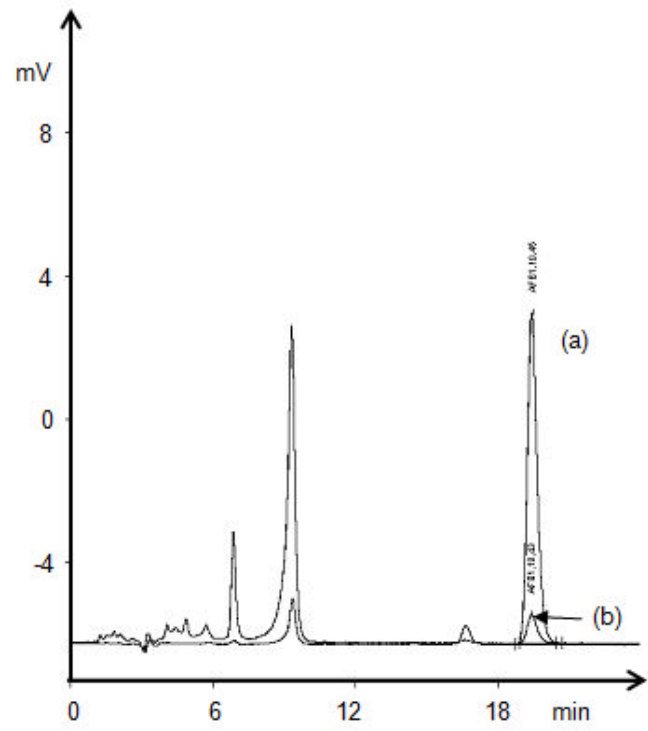

Fig 3. Chromatogram of standard AFB1 in aqueous solution with concentration of $200 \mathrm{ng} / \mathrm{mL}$ (a), and $2000 \mathrm{ng} / \mathrm{mL}$ after being adsorbed with $25 \mathrm{mg}$ zeolite for $3 \mathrm{~h} \mathrm{(b)}$

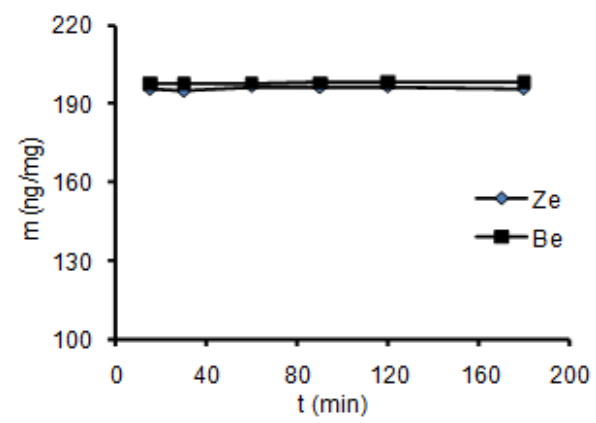

Fig 4. Correlation curve between the amount AFB1 adsorbed $(\mathrm{m})$ versus contact time $(\mathrm{t})$ on adsorbent zeolite $(\mathrm{Ze})$ and bentonite $(\mathrm{Be})$

(80 and 100 mesh) and small size (200 and 400 mesh). Capability of adsorption in a group of particle size is not significant different, especially for zeolite.

\section{Effect of AfB1 Concentration}

As mentioned in the experimental section, the effect of concentration on adsorption was carried out by mixing standard AFB1 solution with adsorbent (constant weight) in a batch system at various initial concentration of AFB1 and other variables (particle size, contact time and weight of adsorbent) constant. An example of standard AFB1 chromatogram before and after adsorption can be seen in Fig. 6 and data of adsorption is expressed in Fig. 7.

From Fig. 6 can be observed that initial concentration up to $2000 \mathrm{ng} / \mathrm{mL}$ the adsorption is still increased indicating very highly capacity of the

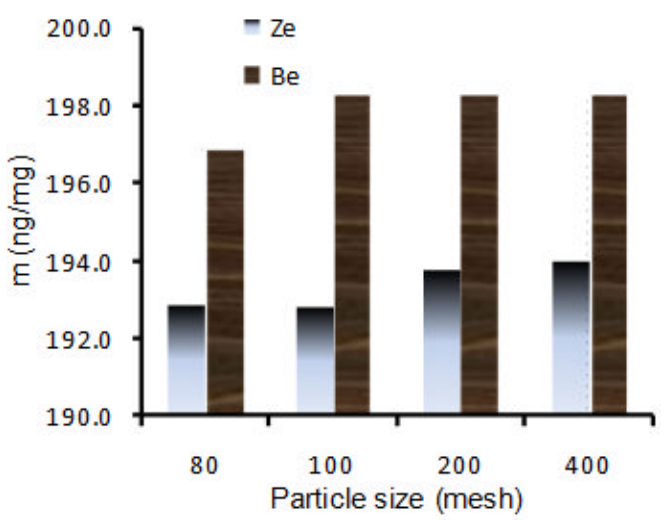

Fig 5. Diagram of correlation between the amount AFB1 adsorbed $(\mathrm{m})$ versus particle size on adsorbent zeolite $(\mathrm{Ze})$ and bentonite $(\mathrm{Be})$

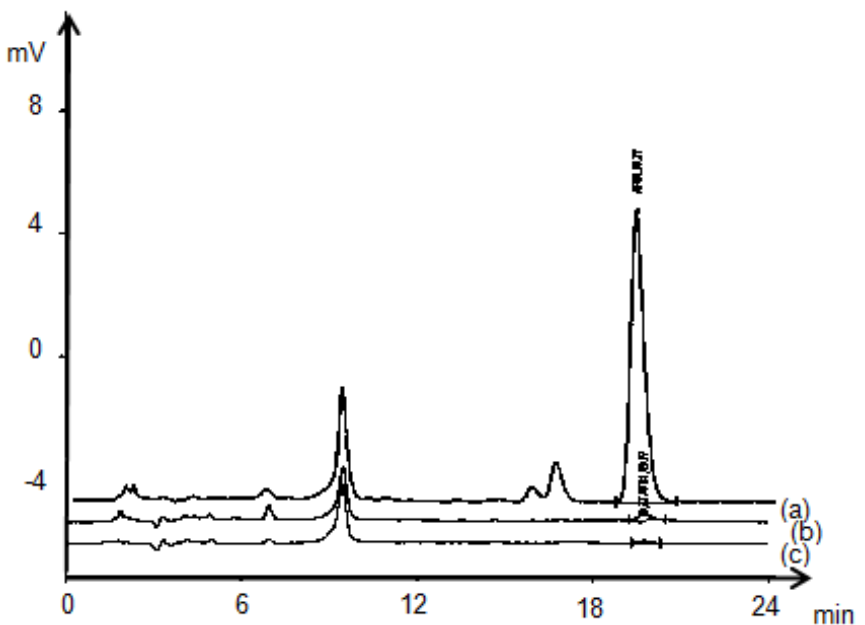

Fig 6. Chromatogram of standard AFB1 $200 \mathrm{ng} / \mathrm{mL}$ (a), $2000 \mathrm{ng} / \mathrm{mL}$ after being adsorbed with zeolite (b) and bentonite (c)

adsorbents for AFB1. Adsorption at higher concentration was not carried out due to low solubility of AFB1 in water. However, if both adsorbents are compared, it can be observed that bentonite gives adsorption capability higher than zeolite does. It is agreed with quantitative evaluation of the experimental data using Freundlich model [20]. The Freundlich model assumes heterogeneous adsorption due to the diversity of the adsorption sites or the diverse nature of adsorbate. The Freundlich model is expressed as:

$\mathrm{m}=\mathrm{K}_{\mathrm{f}} \mathrm{C}^{1 / n}$

where $K_{f}$ is the Freundlich constant related to adsorption capacity of adsorbent and $n$ is the Freundlich exponent related to adsorption intensity. $K_{f}$ and $n$ can be calculated from the slope and intercept of the linear plot of $\log m$ versus $\log C$. Table 2 displays the coefficients of the Freundlich model along with regression coefficients $\left(R^{2}\right)$. From the table can been 


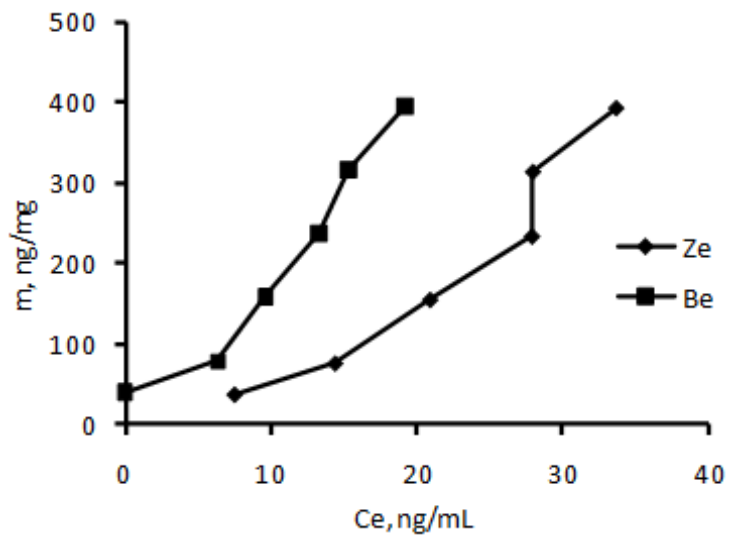

Fig 7. Correlation curve of the amount of AFB1 adsorbed $(m)$ versus concentration of AFB1 in equilibrium $(\mathrm{Ce})$
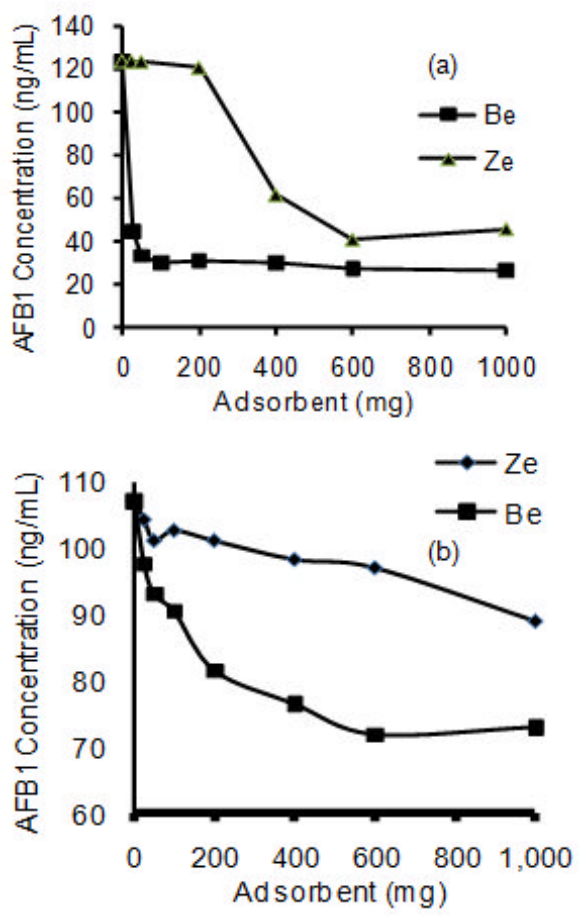

Fig 8. Reduction of AFB1 concentration in grounded (a) and kernel (b) corn by adsorption process

seen that capacity, represented by $K_{f}$, of bentonite is 3.8 fold higher than that of zeolite, even thought the intensity, based on the value of $n$, is not so significant different. This result is different from that reported by Thieu and Pettersson [18]. The adsorption capacities of bentonite and HSCAS for $\mathrm{AFB}_{1}$ were 12.7 and $13.1 \mathrm{mg} / \mathrm{g}$, respectively, from fitting the data to the Freundlich isotherm equation and it is higher than resulted in this work. This supports Gallo and Masoero [19] that media influences the adsorption.

The structure of adsorbent seems to have more important role on the adsorption process rather than the presence of the functional groups. Interlayer space and swelling level of bentonite are suspected as the main factor on higher adsorption capability of bentonite. If the adsorption related to functional groups, based on the infrared spectra, the capability of both adsorbents would be similar. In the other words, capability of adsorption is not depended significantly on the functional group present in the adsorbent and probable on the hydrophobic level. Zeolite, more hydrophobic than bentonite gives fewer tendencies to interact with AFB1. It is consistent with results reported by Daković et al. [22]. Low polar AFB1 had a high affinity for the unmodified zeolitic tuff and the adsorption of AFB1 was greatly reduced for octadecyldimethylbenzyl ammonium modified zeolite. Desheng et al. [17] suggested that the mechanism of AFB1 on montmorillonite was AFB1 sorbed onto the edge of Mont by a double hydrogen bond, and AFB1 molecules did not penetrate into the interlayer area of Mont. Bonding between $\mathrm{AfB}_{1}$ and smectite clay was predicted to appear to be in the furan rings [22]. Other possible bonding is with the two oxygens in the coumarin ring of $\mathrm{AfB}_{1}$ and interlayer cations or their associated water molecules.

\section{Reduction of AFB1 Contamination in Corn}

In this work, AFB1 contaminated corn samples were used and reduction was carried out by mixing aqueous suspension of corn sample with adsorbent in a batch system. Analysis of AFB1 in suspension after and before adsorption process was analyzed using ELISA method and detected with visible spectrophotometer (ELISA reader). For standard AFB1, in the range of $5-50 \mathrm{ng} / \mathrm{mL}$ gives curve represented as correlation between absorbance percentage versus concentration with correlation coefficient, $R^{2}$, of 0.9971 and the equation: \% ABS = -19.164 $\ln [A F B 1]+93.06$.

In the adsorption process, it was expected that AFB1 in corn samples was extracted into aqueous suspension and then adsorbed by adsorbent. A variable examined was adsorbent weight, being varied form 25 to $1000 \mathrm{mg}$ of corn sample at corn weight and water volume constant $5 \mathrm{~g}$ and $10 \mathrm{~mL}$, respectively.

Consistent with adsorption of standard AFB1 in aqueous solution, from Fig. 8 shows that capability of bentonite to adsorb AFB1 in aqueous suspension of corn samples is higher than that of zeolite. However, the capacity of both adsorbents to adsorb AFB1 in aqueous solution is much higher than in corn suspension. Zeolite and bentonite $(25 \mathrm{mg})$ are able to adsorb completely AFB1 99 and 96\%, respectively, of $200 \mathrm{ng} / \mathrm{L}(1.0 \mathrm{mg})$ in aqueous solution, but only 9.5 and $33.0 \%$, respectively, of $107 \mathrm{ng} / \mathrm{mL}(1.6 \mathrm{mg})$ in suspension of kernel corn, and 67.3 and $78.1 \%$ in grain 
corn suspension. It is not surprising because corn aqueous suspension contains various types of aflatoxins, even other mycotoxins, leading to competition among them in adsorption.

Evaluation of the capacity of cation type of different bentonites to adsorb aflatoxins in different media has been reported by Gallo and Masoero [19]. The AFB1 and AFG1 used were extracted from a contaminated corn meal $(82.21 \mathrm{mg} / \mathrm{kg}$ of AFB1 and $97.20 \mathrm{mg} / \mathrm{kg}$ of AFG1). Three single-concentration adsorption tests, consisting of a simply-water (W), a gastro-intestinal simulating monogastric model (MM) and a ruminant model (RM) were used. The AfB1 and AfG1 recovered in controls were 92.3 and $104.9 \%$ in $W$ and 89.5 and $101.5 \%$ in $\mathrm{MM}$; while in RM were 65.2 and $81.9 \%$, respectively. This supported that intrinsic rumen fluid factors could be involved in sequestering of aflatoxins. The sequestering agents $(\mathrm{Mg}$ bentonite and $\mathrm{Na}$ bentonite) were very efficient to sequester the available AfB1, with a sequestering activity of over $99.0 \%$ with each method.

\section{CONCLUSION}

The findings of this study indicated that result shows that adsorption of AFB1 on adsorbents of natural zeolite and bentonite is very fast. Within $15 \mathrm{~min} 99 \%$ of AFB1 (200 ng/mL) has been adsorbed by $25 \mathrm{mg}$ of bentonite and $96 \%$ by zeolite. The particle size higher than 200 mesh did not give significant effect on the AFB1 adsorption capability. In comparison, effectiveness of zeolite in adsorbing AFB1 is lower than that of bentonite. The difference is probable caused by the structure rather than the present functional groups of the adsorbents. It was supported by data of infrared spectroscopy indicating similarity of spectra and $\mathrm{x}$-ray diffraction (XRD) data showing different pattern. Capability in reducing AFB1 contamination in corn samples (kernel and meal) for both adsorbents is lower than that in standard solution. Adsorbent $(1.0 \mathrm{~g})$ of zeolite and bentonite reduce 17 and $37 \%$, respectively, of AFB1 (107 ng/mL) in kernel corn suspension and 78 and $67 \%$, respectively, of AFB1 $(124 \mathrm{ng} / \mathrm{mL})$ in grained corn suspension. Other mycotoxins contained in the corn samples are predicted as main factor of the decrease of adsorption capability.

\section{ACKNOWLEDGEMENT}

Thanks to the Institute of Research and Community Services, Universitas Gadjah Mada through International Collaboration Research Grant for the financial support, the Austrian Federal Ministry for Science and Research (BMWF) in the frame of ASEA UNINET for the scholarship and Rina Kuniawati for the assistance in collecting research data.

\section{REFERENCES}

1. Abdel-Wahhab, M.A., Nada, S.A., and Amra, H.A., 1999, J. Appl. Toxicol., 19, 3, 199-204.

2. Abdel-Wahhab, M.A., and Aly, S.E., 2003, J. Agric. Food Chem. 51, 8, 2409-2414.

3. Park, J.W., Kim, E.K., Shon, D.H., and Kim, Y.B., 2002, Food Addit. Contam., 19, 11, 1073-1080.

4. Ali, N., Sardjono, Yamashita, A., and Yoshizawa, T., 1998, Food. Addit. Contam., 15, 4, 377-384.

5. Noviandi, C.T., Razzazi, E., Agus, A., Böhm, J., Hulan, H.W., Wedhastri, S., Maryudhani, Y.B., Nuryono, Sardjono, and Leibetseder, J., 2001, Mycotoxin Res., 17A, 2, 174-177.

6. Bahri, S., Ohim, and Maryam, R., 1995, Residu aflatoksin M1 pada susu sapi dan hubungannya dengan keberadaan afaltoksin B1 pada pakan sapi, Kumpulan Makalah Lengkap Kongres Nasional Perhimpunan Mikologi Kedokteran Manusia dan Hewan Indonesia I dan Temu IImiah, Bogor, 21-24 Juli 1994, 269-275

7. Nuryono, Agus, A., Wedhastri, S., Maryudani, Y.B., Sigit Setyabudi, F.M.C., Böhm, J., and RazzaziFazeli, E., 2009, Food Control, 20, 8, 721-724.

8. Maryam, R., Bahri, S., and Zahari, P., 1994, Deteksi aflatoksin B1, M1 dan Aflatoksikol dalam Telur dengan Kromatografi Cair Kinerja Tinggi, Prosiding Teknologi Veteriner untuk Kesehatan Hewan dan Keamanan Pangan, Bogor, 22-24 Maret 1994.

9. Maryam, R., 1996, Residu Aflatoksin dan Metabolitnya dalam daging dan Hati Ayam, Prosiding Temu IImiah Nasional Bidang Veteriner, Bogor, 12-13 Maret 1996, 236-339.

10. Hall, J.A., and Wild, P.C., "Epidemiology of aflatoxins related disease", in The toxicology of aflatoxins, L.D. Eaton and J.D. Groopman ed., London: Academic Press, Inc., 1994, 233-258.

11. Sudjadi, S., Machmud, M., Damardjati, D.S., Hidayat, A., Widowati, S., and Widiati, A. 1999. Aflatoxin research in Indonesia. Elimination of Aflatoxin Contamination in Peanut, Australian Centre for International Agricultural Research, Canberra, 23-25.

12. Anderson, R.A., "Detoxification of aflatoxin contaminated corn" in Aflatoxin and Aspergillus flavus in Corn Southern Cooperative Series Bulletin 279, Diener, U., Asquith, R., Dickens, J. ed., Auburn University, Auburn, AL, 1983, 87-90.

13. Bintvihok, A., 2002, Feed Tech., 6, 1, 28-29. 
14. Phillips, T.D., Kubena, L.F., Harvey, R.B., Taylor, D.R., and Heidelbaugh, N.D., 1988, Poult. Sci., 67, 2, 243-247.

15. Abdel-Wahhab, M.A., Nada, S.A., and Khalil, F.A., 2002, Animal Feed Sci. Technol., 97, 3, 209-219.

16. Aly, S.E., Abdel-Galil, M.M., and Abdel-Wahhab, M.A., 2004, Food Chem. Toxicol., 42, 11, 18251831.

17. Desheng, Q., Fan, L., Yanhu, Y., and Niya, Z., 2005, Poult. Sci., 84, 6, 959-961.

18. Thieu N.Q., and Pettersson, H., 2008, Mycotoxin Res., 24, 3, 124-129.
19. Gallo, A., and Masoero, F., 2010, Ital. J. Anim. Sci., 9, 1, 109-116.

20. Ramesh, A., Hasegawa, H., Sugimoto, W., Maki, T., and Ueda, K., 2008, Bioresour. Technol., 99, 9, 3801-3809.

21. Daković, A., Tomasević-Canović, M., Dondur, V., Rottinghaus, G.E., Medaković, V., and Zarić, S., 2005, Colloids Surf., B, 46, 1, 20-25.

22. Arvide, M.G.T., Mulder, I., Velazquez, A.L.B., and Dixon, J.B., 2008, Clays Clay Miner., 56, 5, 571578. 